\title{
DEVELOPMENT IMPACT, PUBLIC-PRIVATE PARTNERSHIPS AND REGIONAL INTEGRATION: POSSIBLE WAY-FORWARD FOR THE BRICS-LED NEW DEVELOPMENT BANK
}

\author{
Karin Costa Vazquez ${ }^{1}$
}

\begin{abstract}
The BRICS-led New Development Bank (NDB) stated commitment to infrastructure and sustainable development financing is perhaps the single-most important feature that differentiates it from other existing Multilateral Development Banks (MDBs). In the absence of a clear definition and criteria to qualify the very notion of "sustainable infrastructure", however, it will be challenging for the NDB to designate infrastructure as sustainable and realize its vision around sustainable development. This paper argues that the NDB is presented with an opportunity to define sustainable infrastructure and pioneer a new approach to development financing. It further suggests that the NDB should look into developing public-private partnerships and regional integration projects as options going forward. This approach would equip the NDB with the necessary policy tools to fully articulate its mandate and carve out a niche for itself in the development finance landscape.
\end{abstract}

Keywords: sustainable development; infrastructure; New Development Bank; BRICS; development cooperation.

\section{IMPACTO NO DESENVOLVIMENTO, PARCERIA PÚBLICO-PRIVADA E INTEGRAÇÃO REGIONAL: CAMINHOS POSSÍVEIS PARA O NOVO BANCO DE DESENVOLVIMENTO DO BRICS}

O Novo Banco de Desenvolvimento (NDB), liderado pelo BRICS, declarou que o compromisso com o financiamento de infraestrutura e desenvolvimento sustentável é talvez a característica mais importante que o diferencia de outros Bancos Multilaterais de Desenvolvimento (Multilateral Development Banks - MDBs) existentes. A ausência de uma definição e de critérios claros para qualificar a própria noção de "infraestrutura sustentável", no entanto, será um desafio para o NDB designar infraestrutura como sustentável e realizar sua visão em torno do desenvolvimento sustentável. Este artigo argumenta que o NDB tem a oportunidade de definir uma infraestrutura sustentável e abrir uma nova abordagem para o financiamento ao desenvolvimento. Além disso, sugere que o NDB deva considerar o desenvolvimento de parcerias público-privadas e projetos de integração regional como opções a serem perseguidas. Essa estratégia daria ao NDB as ferramentas necessárias para articular o seu mandato e criar um nicho para si próprio na arquitetura global do financiamento para o desenvolvimento.

Palavras-chave: desenvolvimento sustentável; infraestrutura; Novo Banco de Desenvolvimento; BRICS; cooperação para o desenvolvimento.

1. Fudan Scholar, School of International Relations and Public Affairs and Center for BRICS Studies at Fudan University, China. Associate professor, assistant dean for global engagements, and executive director of the Center for African, Latin American and Caribbean Studies at O.P. Jindal Global University, India. This paper is partially based on a section of the report Building infrastructure for $21^{\text {st }}$ Century Sustainable Development: lessons and opportunities for the BRICSled New Development Bank, which was led by the author. 


\section{IMPACTO EN EL DESARROLLO, ASOCIACIÓN PÚBLICO-PRIVADA E INTEGRACIÓN REGIONAL: CAMINOS POSIBLES PARA EL NUEVO BANCO DE DESARROLLO DEL BRICS}

El Nuevo Banco de Desarrollo (NDB) liderado por BRICS declaró que el compromiso con la infraestructura y el financiamiento del desarrollo sostenible es quizás la característica más importante que lo diferencia de otros bancos multilaterales de desarrollo (BMD) existentes. Sin embargo, en ausencia de una definición clara y de criterios para calificar la noción de "infraestructura sostenible" será un desafío para el NDB designar a la infraestructura como sostenible y concretizar su visión de desarrollo sostenible. El argumento de este artículo es que el NDB tendría la oportunidad de definir "infraestructura sostenible" y ser pionero en un nuevo enfoque para el financiamiento del desarrollo. Sostiene además que el NDB debería considerar la posibilidad de realizar asociaciones público-privadas y proyectos de integración regional como opciones futuras. Este enfoque equiparía al NDB con las herramientas necesarias para articular plenamente su mandato y liderar el financiamiento para el desarrollo.

Palabras clave: desarrollo sostenible; infraestructura; Nuevo Banco de Desarrollo; BRICS; cooperación para el desarrollo.

JEL: F50.

Data de envio do artigo: 2/3/2020; Data de aceite: 31/3/2020.

\section{INTRODUCTION}

In 2015, a new international architecture for sustainable development began to take shape. Building on the United Nations' Financing for Development Agenda in Addis Ababa and the formal adoption of the Sustainable Development Goals (SDGs), the year culminated in the Conference of Parties 21 in Paris. Almost 190 countries accounting for more than $98 \%$ of greenhouse-gas emissions agreed to a global climate-change strategy. Attention now shifts toward how to implement and finance sustainable development.

Each country submitted a voluntary plan that sets out how it will move the economy onto a lower-carbon growth pathway. While these voluntary plans will take years to play out, one likely effect is to direct investments toward more sustainable projects, including infrastructure. Given the scale of investment required, creating the right conditions for this investment is essential. From 2015 to 2030, global demand for new infrastructure could amount to more than US\$ 90 trillion from a total estimate of US\$ 50 trillion in 2015. Investing in infrastructure in a sustainable fashion will likely increase up-front capital $10 \%$ costs by $6 \%$ for individual projects.

The trillion-dollar infrastructure financing gap figures amongst the reasons why emerging economies have decided to set up new structures of multilateral cooperation. In 2015, the New Development Bank (NDB) was established by the BRICS countries with the purpose of mobilizing resources to finance infrastructure and sustainable development in emerging markets and developing countries. 
The NDB's stated commitment to infrastructure and sustainable development is perhaps the single most important feature that differentiates it from other Multilateral Development Banks (MDBs). However, in the absence of a clear definition and criteria to qualify the very notion of 'sustainable infrastructure', it will be challenging for the NDB to designate infrastructure as sustainable and realize its vision around sustainable development.

In May 2016, the board of directors of the NDB met on the sidelines of the World Bank and the International Monetary Fund spring meetings in Washington, D.C., to approve its first set of loans worth US\$ 811 million. By the end of 2016, a total of seven projects in all member countries worth over US\$ 1.5 billion had been approved. With the exception of financing a road project in the state of Madhya Pradesh, in India, the NDB's funds have been earmarked for renewable energy projects across the BRICS countries, including two solar energy projects in India and China, a wind power plant in China, a small-scale hydropower dam in Russia, and a credit line worth US\$ 300 million to finance renewable energy projects such as solar and wind power, in Brazil. The NDB's apparent prioritization of renewable energy projects thus seems to reflect its stated intention to support sustainable development across the BRICS countries.

In August 2017, the NDB Board of Directors approved four new projects in China, Russia, and India with loans aggregating over US\$ 1.4 billion. The second tranche of projects broadened the scope of NDB's activities to areas ranging from information technology to energy conservation, although the focus still appears to be to support sustainable development. Projects include a US\$ 2 billion sovereign project finance facility for flood control and water quality in China's Hunan province and a US\$ 470 million sovereign project loan for developing the rural drinking water supply scheme in the Indian state of Madhya Pradesh. The approval of at least US $\$ 32$ billion in loans and the financing of up to 67 additional projects by 2021 have also been announced. ${ }^{2}$

As the NDB consolidates its operations, it is challenged by its commitment to sustainability. In four years, the NDB has built a portfolio of 50 approved projects worth more than US\$ 17 billion in areas such as renewable energy, sanitation, irrigation, and transportation. ${ }^{3}$ The NDB Board of Directors has approved non-sovereign loans including one of US\$ 300 million to Sibur Holding for the construction of water treatment facilities, transport and logistics infrastructure, one of US\$ 200 million to Petrobras for the upgrading of two refineries and improving companies' environmental performance, and one of up to US\$ 100 million to equity investment in the private equity fund Patria Infrastructure Fund IV, L.P. 
to catalyze investments in Brazil's key infrastructure sectors. In 2019, the first transnational project was approved, financing the construction of a dam and tunnel to transfer water from Lesotho to South Africa. More recently, a US\$ 1 billion emergency assistance program to China to combat the outbreak of the novel coronavirus disease (COVID-19) was approved.

However, the criteria by which projects are selected and monitored remain unclear. So are the development results achieved. In South Africa, doubts loom over NDB loans to the indebted energy company Eskom. The non-governmental organization (NGO) community has been voicing its concerns on the threats that the expansion of the Durban port and the refurbishment of the Medupi coal-fired power plant pose on local communities in South Africa, including environmental degradation and increased carbon emissions (Bond, 2019). In India, a road modernization project in Madhya Pradesh is suspect of land eviction and property destruction. ${ }^{4}$

Pressure for the NDB to designate infrastructure as sustainable and realize its vision around sustainable development is likely to increase as the bank expands its portfolio, prepares its second General Strategy 2022-2027, and appoints its next president in 2020. This paper argues that the NDB is presented with an opportunity to conceptualize sustainable infrastructure and pioneer a new approach to multilateral development financing. The paper further suggests that the NDB should look into developing public-private partnerships and regional integration projects as options to fully articulate its mandate in countries like Brazil and carve out a niche for itself in the global development finance landscape. These points will be discussed in the following sessions.

\section{BRICS PUSH FOR INFRASTRUCTURE IN THE GLOBAL DEVELOPMENT AGENDA}

With an aggregate growth from $8 \%$ in 2001 to nearly $20 \%$ of global gross domestic product (GDP) in 2011, the emerging economies of Brazil, Russia, India, and China have performed better than Goldman Sachs economist Jim O'Neill projected when he first wrote about them as a unit nearly two decades ago. The BRIC has come a long way since its first summit in 2009 and the induction of South Africa the following year. Today, the five countries together represent approximately $40 \%$ of the total world's population, $30 \%$ of the total land area, and $25 \%$ of global GDP. The BRICS has emerged as an alternative to the Bretton Woods system and has taken concrete steps in this direction through the creation of new alliances and institutions like the NDB and the Contingent Reserve Arrangement.

4. Available at: <http://www.bricsfeministwatch.org/pdf/NDB-India-project-key-findings.pdf>. 
Whilst recognizing the potential of the BRICS to articulate a new development agenda, critics claim that the five countries would be simply creating new forms of power asymmetry. This view is based on the narrative that the BRICS arose within the international financial system and would take advantage of it to consolidate itself. This would be a proof that the current global governance system stands still and though the players may change, the structures remain the same. New groupings and institutions would, therefore, seek to integrate themselves into the existing system while trying to retain the highest possible degree of sovereignty and autonomy (Kahler, 2013), echoing Ikenberry's assertion that the current liberal world order is "easy to join, but hard to overturn" (Ikenberry, 2008).

Questions also persist around the extent to which the BRICS pursues the needs of the people of the Global South. Poverty headcount ratio remains relatively high in virtually all five members. In India, $23.63 \%$ of the population was found to live under US\$ 1.25 a day in 2013, followed by South Africa with $9.42 \%$ China with $6.26 \%$ and Brazil with 4.53\%. In South Africa, India and China, rural dwellers are increasingly poorer compared to their urban counterparts. Approximately $50 \%$ of China's rural population is excluded from public benefits such as health insurance and higher levels of education. Girls remain in a disadvantaged position with regard to access to education in all the five countries. ${ }^{5}$

Infrastructure can play a vital role in promoting economic growth while ensuring deprived sections of the population to experience welfare. Yet, insufficient funding has been claimed as the primary reason behind stagnating infrastructure projects and crippled development in the BRICS and the Global South. On the one hand, commercial banks have tightened investments in infrastructure after the 2008 global financial crisis. On the other hand, Western donors have shied away from infrastructure investment as MDBs embraced the Washington Consensus and shifted from infrastructure investment to policy lending targeted at institutional reforms in developing countries (Borges, 2016).

It is in this context that Brazil, Russia, India, China, and South Africa announced at the $5^{\text {th }}$ BRICS Summit in 2013 their decision to set-up a new development bank in an effort to provide sufficient funding for infrastructure development. ${ }^{6}$ The agreement to establish the NDB was signed the following year at the $6^{\text {th }}$ BRICS Summit, when the five countries agreed to an initial authorized capital of US\$ 100 billion. Lending operations started two years later, in 2016.

5. Available at: <http://www.eldis.org/document/A67121>.

6. Available at: <http://brics2016.gov.in/upload/files/document/5763be1c4da6e5th1.pdf>.

7. Available at : <http://www.itamaraty.gov.br/en/press-releases/5705-vi-brics-summit-fortaleza-declaration-july-15-2014>. 
In June 2017, the Board of Governors of the NDB released its first General Strategy 2017-2021 in which the bank states its commitment to be "new" in three areas: i) relationships; ii) projects and instruments; and iii) approaches. With regard to projects and instruments, the NDB General Strategy 2017-2021 states that "sustainable infrastructure" will be the NDB's main focus, with approximately two-thirds of all projects devoted to this area. However, the NDB's focus on sustainable infrastructure puts the organization in a conundrum as it collapses at least two "partially incompatible priorities." This could be on account of two main reasons. First, the heavy social and environmental costs of infrastructure projects generally cannot be offset by a separate set of sustainable development projects. Second, even "green infrastructure" projects such as solar and wind energy, can generate negative impacts, especially in the absence of a robust set of standards for environmental and social assessment and risk management or weak monitoring mechanisms.

The NDB General Strategy 2017-2021 broadly defines sustainable infrastructure as "infrastructure that incorporates economic, environmental and social criteria in its design, building, and operation." It adds that "traditional evaluation methods fail to account for numerous factors that have a major influence on a project's viability and developmental impact in the medium and long-run" (Vazquez, Roychoudhury e Borges, 2017). But apart from stating that sustainable development will be linked to the financing of infrastructure projects and that evaluation methods are insufficient to measure the impact of these projects, the NDB has been less clear about how it will generate medium and long-term positive developmental impact.

\section{WHAT CAN THE NDB LEARN FROM OTHER MDBS?}

When the idea of a BRICS-led development bank was first announced seven years ago, it was met with a range of reactions from wariness to cautious optimism to overt celebration. Almost from day one, it was seen to be a direct challenge to the Western-dominated World Bank and International Monetary Fund (IMF). BRICS governments have maintained that their bank serves to complement and not substitute these institutions. It is in this spirit that the NDB can draw from the experience of long-established MDBs to chart its own unique path, including how to define sustainable infrastructure and assess the sustainability of its projects.

For most MDBs, sustainable infrastructure is loosely defined as the infrastructure that is socially, economically and environmentally sustainable with varying degrees of emphasis. Other organizations like the International Finance

8. Available at: <https://www.cigionline.org/publications/infrastructure-and-sustainable-development-goals-brics-lednew-development-bank>. 
Corporation (IFC) add a fourth dimension - financial sustainability. ${ }^{9}$ Building on its own interpretation of sustainable development, the African Development Bank $(\mathrm{ADB})$ defines sustainable infrastructure in terms of the operational functioning and efficiency of the physical infrastructure built. Sustainable infrastructure is therefore defined by "internal project" elements like environmental sustainability, low-carbon, and climate-resiliency of the materials and processes employed. ${ }^{10,11}$

Although it is unrealistic to develop a shared definition of sustainable infrastructure, there is a need to develop a harmonized framework and guiding principles for infrastructure project allocation. These principles and framework would focus on common building blocks of sustainable development and promote convergence around sustainable infrastructure among development finance institutions, institutional investors and private banks. The ADB defines sustainable infrastructure based on principles like: i) promoting low-carbon development and minimizing impacts on local environments; ii) advancing solutions that help communities deal with the unavoidable impacts of climate change; iii) improving the access of poor people to education, health, and basic social protections, as well as to markets and productive assets; iv) emphasizing gender equality and the empowerment of women; $v$ ) improving the transparency and efficiency of public resource management; and vi) attracting direct private sector investments that support inclusive growth and improve the environment.

MDBs experience also show the need to place sustainability at the core of infrastructure planning. The Inter-American Development Bank (IADB) proposes a shift to a sustainable infrastructure focus through the incorporation of critical components of environmental sustainability from the very start of the project cycle, so that they are present as a core focus of infrastructure planning. In the IFC, the principles enshrined in the sustainability framework require clients to include greenhouse gas emissions in their regular reporting; set the responsibility of business to respect human rights, independently of the state duties to respect, protect, and fulfill human rights. IFC sustainable infrastructure projects are also guided by the International Bill of Human Rights and the eight core conventions of the International Labor Organization. ${ }^{12}$

Overall, $\mathrm{MDBs}$ articulate their approach towards infrastructure and sustainable development at two levels. The first level ("aspirational") is where these

9. Available at: <https://www.ifc.org/wps/wcm/connect/topics_ext_content/ifc_external_corporate_site/sustainabilityat-ifc/business-case $>$.

10. Available at: <https://think-asia.org/bitstream/handle/11540/2987/environment-operationaldirections-2013-2020.pdf? sequence $=1>$.

11. Available at: <https://publications.iadb.org/publications/english/document/Sustainable-infrastructure-forcompetitiveness-and-inclusive-growth.pdf>.

12. Available at: <http://documents.worldbank.org/curated/en/555031481193874203/pdf/110838-WP-IFCSustainability-Framework.pdf>. 
organizations reaffirm their strategic and corporate commitment to principles and values of sustainable development. In most cases, the commitments are linked to frameworks such as the SDGs and the Paris Agreement. The next level ("pragmatic") is connected to the first one in the sense that, in order to achieve the goals enshrined in such frameworks and to realize the vision of sustainable development as per their own internal policies, these institutions normally understand that it is at the level of project design and implementation that sustainability should "materialize." This is where safeguards play a key role in ensuring that the operations of the banks are "ustainable" by "doing no harm" to the communities, the environment, and rights-holders potentially affected by their activities (Vazquez, Roychoudhury e Borges, 2017).

The negative spillovers of sustainable infrastructure projects on the environment and local communities are normally corrected via safeguards. MDBs monitor the safeguard performance of their portfolio and identify potential compliance concerns as well as areas for improvement. A basic principle of existing safeguard policies is that implementation of the provisions of the policies is the responsibility of the borrowing country. Clients are usually required to undertake social and environmental assessments, carry out consultations with affected people and communities, prepare and implement safeguard plans, monitor the implementation of these plans, and prepare and submit monitoring reports. MDBs' role is to explain policy requirements to clients, help them meet those requirements during project processing and implementation through capacity-building programs, ensure due diligence, and provide monitoring and supervision (Vazquez, Roychoudhury e Borges, 2017).

By adopting safeguards, MDBs can also manage socio-environmental risks and bypass costly future project delays. Most MDBs see safeguards as a risk management mechanism. The IFC, for instance, helps infrastructure clients mitigate risks by advising them on how to build their overall environmental and social management capacity and adopt the organization's performance standards. The performance standards provide guidance on how to identify risks and impacts and are designed to help avoid, mitigate, and manage risks and impacts as a way of doing business in a sustainable fashion, including stakeholder engagement and disclosure obligations of the client in relation to project-level activities. ${ }^{13}$ Reconciliation is usually ensured through the compliance advisor/ombudsman and regular supervision. The compliance advisor/ombudsman responds to complaints from project-affected communities with the goal of enhancing social and environmental outcomes on the ground.

13. Available at: <https://www.ifc.org/wps/wcm/connect/topics_ext_content/ifc_external_corporate_site/ sustainability-at-ifc/publications/publications_handbook_pps\#: : :text=IFC\%20Performance\%20Standards\%20 on $\% 20$ Environmental,Sustainability $\% 20 \% 2$ D $\% 20$ Effective $\% 20$ January $\% 201 \% 2$ 2 $\% 202012 \&$ text=IFC's $\% 20$ Sustainability\%20Framework\%20articulates\%20the,IFC's\%20approach\%20to\%20risk\%20management>. 


\section{CONCEPTUALIZING SUSTAINABLE INFRASTRUCTURE}

In the previous session we saw that MDBs emphasize a safeguards-oriented (herein referred to as "do no harm") approach to prevent local communities from being disproportionately affected by projects. But this approach limiting in that safeguards do not necessarily unlock the transformational nature of development. Sustainable infrastructure projects could be made to be transformational if they guarantee benefits to both the environment and society at large. In other words, sustainable infrastructure projects should not only aim to avoid, compensate or mitigate adverse impacts on the environment and vulnerable groups but go beyond the "do no harm" approach to consciously generate additional and positive spillovers for both the community and the environment.

Here, transformation is broken down into five dimensions: national development, systemic approach, territorial planning, innovation and financial viability. First, sustainable infrastructure projects are transformational when they reflect the needs and priorities in the national development plans, low carbon development, and resilience policies. At the regional level, aspirations for transformation are conceived in terms of infrastructure's potential to support initiatives like the Belt and Road Initiative and Africa's "accelerated integration and growth, technological transformation, trade and development," ${ }^{14}$ articulated in documents like the African Union's Agenda 2063, the Africa we want and largely operationalized through the Program for Infrastructure Development in Africa. At the global level, transformation is translated in the SDGs and countries' commitments to sustainable and inclusive development. In the case of SDG 9, transformational infrastructure can be interpreted as a resilient infrastructure that promotes inclusive and sustainable industrialization with an aim to foster innovation.

Second, sustainable infrastructure projects are transformational when they have a systemic approach. Modern definitions of sustainable development emphasize human ecosystems as a goal. To achieve this goal, an integrated vision of development or a "systemic approach" that looks at cross-sectoral coordination and integration of environmental, social, and economic concerns throughout the development process should prevail over a siloed "sectoral approach." Environment and all its components also need to be looked at closely to ensure that projects do not have negative spillovers from one system to another.

The third dimension is territorial planning. Infrastructure projects are commonly designed and implemented without prior assessment of the needs and vulnerabilities of the territory. This deficiency curbs infrastructure capacity to 
contribute to local and regional long-term development and to leave a positive legacy. A nuanced approach to sustainable infrastructure that emphasizes countries' growth priorities and trajectories should not eclipse the importance of ensuring that sustainable infrastructure is meant to translate into development at the level of the territory where the project is located. Hence, sustainable infrastructure adapts not only to country characteristics but also to local and regional development aspirations.

Finally, a transformational sustainable infrastructure project is innovative and financially sustainable. Innovation should be looked at in two ways: creating new sustainable infrastructure; and making existing infrastructure more sustainable by building on local knowledge, national experiences, and international practices. Often loan allocation results in huge debts for the borrowing country, which further hamper their development process. Financial sustainability should be looked beyond project feasibility to ensure projects do not turn into white elephants and neither the lender nor borrower incurs in bad loans.

As the NDB strives to maintain the "new" in its name, the bank could create metrics to assess the transformational potential of its projects as well as financial and non-financial incentives to encourage clients to prepare and submit 'transformational' projects to the bank. Linking sustainable development to incentives would encourage borrowers to think about sustainable practices not as bureaucratic formalities or risks, but as actions ultimately linked to better development outcomes.

\section{PUBLIC-PRIVATE PARTNERSHIPS AND REGIONAL INTEGRATION AS THE ROAD AHEAD}

In addition to conceptualizing sustainable infrastructure and assessing the development impact of its projects, another challenge ahead of the NDB is how to ensure balanced loan allocation among the banks five-member countries. This year, China passed India as the main beneficiary of the NDB, with $47 \%$ versus $24 \%$ of total lending. Russia and South Africa follow in third and fourth place, with 13\% and $11 \%$ respectively. Brazil receives the lowest amount, totaling approximately US\$ 1.5 million (9\%) of NDB loans. ${ }^{15}$ One of the distinguishing features of the $\mathrm{NDB}$, the equal voice in the bank's governance would be short-lived without a balanced allocation of loans among the five members.

Political and operational factors help explain the relatively low amount of funds that Brazil receives from the NDB. For many years Brazil has underplayed its participation in the bank. Brazil and Russia are the only BRICS countries that have never sent their ministers of Finance to NDB annual meetings. Unlike 
Russia, the first country to integrate its paid-in shares ahead of schedule, Brazil has recurrently delayed the payment of its contribution. The number of Brazilian nationals among the bank's staff has also been consistently low compared to the other four members. On the sides of the $11^{\text {th }}$ BRICS Summit, minister of Economy and Brazilian representative to NDB's Board of Governors Paulo Guedes expressed his support to the NDB, in what seemed an attempt to reinvigorate Brazil's participation in the NDB and to promote the bank as a catalyst of infrastructure investment. The sensitization of the highest echelons of the Brazilian government to the potential of the NDB is particularly timely as Brazil takes the presidency of the NDB in 2020.

The operational challenges are mainly related to how external public sector financing is managed in Brazil. Projects and programs financially supported by external sources and submitted to the External Financing Commission (Comissão de Financiamentos Externos - COFIEX) take an average of three years until they are ready for signature as opposed to the six-months promised by the NDB. Conceived to be a competitive advantage of the NDB over long-established MDBs, the six-month period for the bank to appraise, negotiate and approve loans seems to better suit the political system of countries like China and India than Brazil. In addition to these challenges are COFIEX funding thresholds and the limited capacity of Brazilian states to take on new loans. This is particularly problematic in the context of the financial crisis affecting a growing number of subnational entities across the country.

The opening of the NDB's Regional Office of the Americas in São Paulo and the satellite office in Brasília in late 2019 comes to the rescue of the bank's operations in the country. But as important as attracting new projects is how the regional office will assist the NDB in thinking its business model in Brazil. One route is to make greater use of the Investment Partnership Program (PPI) and other existing programs and funds to build a pipeline of loans with sovereign guarantee and fast-track the process within COFIEX. Another route is to rely more heavily on private sector financing. Today, approximately $85 \%$ of the bank's portfolio consists of loans with sovereign guarantee. In Brazil, this percentage decreased from 100\% to 68\% after the approval of a US\$ 200 million credit to Petrobras in 2018. After the opening of the NDB Regional Office of the Americas, two new loans of US\$300 million to Vale and of US\$ 100 million to an equity fund were approved, bringing the percentage of loans with sovereign guarantee further down to $61 \%$. Greater coordination with bilateral business councils and the BRICS business council could help consolidate this trend and give the bank a competitive edge in markets like Brazil. 
The NDB Regional Office of the Americas could also play a role in promoting economic integration projects in Latin American - a historically in-demand area that gains new momentum with the opportunity to further insert the region into new global value chains. Economic integration features in the NDB General Strategy 2017-2021 as one of the priority areas, but the bank has not yet approved any project under this workstream in Latin America. One of the possible reasons for the absence of economic integration projects in the region is that the NDB board of governors can only approve projects in member countries. Projects in a non-member emerging economy or developing country can only be approved on an exceptional basis, thus limiting the catalytic role that the bank can play in financing development on a regional scale.

\section{FINAL REMARKS}

The BRICS countries are the largest investors in infrastructure, with $40 \%$ of global investments in the sector. According to NDB's own projections, these investments should reach $42 \%$ by 2030 , from which approximately $22 \%$ are expected to come from NDB loans. As the bank approaches the end of its first five-year strategy and transitions from a start-up to an established venture, it is presented with an opportunity to pioneer new approaches to development financing. This includes expanding the "do no harm" approach typically adopted by MDBs to complementarily incorporate a more "transformative" approach towards development. Offering financial and non-financial incentives like better loan conditions and differentiated services to projects that can generate positive transformation could make sustainable infrastructure projects more attractive while discouraging those that hinder the attainment of sustainability goals. Reaching out to local actors, including the private sector, and funding economic integration projects would further equip the NDB with the necessary policy tools to realize its vision around infrastructure and sustainable development.

Careful and detailed monitoring of the results of the NDB projects under a framework that considers both the "do no harm" and the "transformational" aspects of sustainable infrastructure investment should be a key element of future research. This framework could be jointly designed with scholars from the BRICS countries and in consultation with locally-based institutions as part of an effort to create a permanent knowledge sharing platform for collaboration, consultation and exchange. It will be useful for determining whether, how, when, and where the NDB is living up to its promise to support the transition to sustainable infrastructure and the SDGs in a way that is complementary to long-established MDBs. 


\section{REFERENCES}

BOND, P. The BRICS New Development Bank: corruption-riddled development finance. Global Research, 30 Mar. 2019. Available at: <https:// www.globalresearch.ca/corruption-riddled-development-finance-brics-ndbannual-meeting-cape-town/5673103>.

BORGES, C. Optimism, skepticism, and pragmatism: the clashing narratives on the rise of new actors in the international development finance. In: ASIL ANNUAL MEETING, 110., 2016, Washington. Proceedings... Washington: ASIL, 2016.

IKENBERRY, J. G. The rise of China and the future of the West: can the liberal system survive? Foreign Affairs, v. 87, n. 1, p. 23-37, Jan./Feb. 2008.

KAHLER, M. Rising powers and global governance: negotiating change in a resilient status quo. International Affairs, v. 89, n. 3, p. 711-729, 2013.

VAZQUEZ, K. C.; ROYCHOUDHURY, S.; BORGES, C. Building infrastructure for $\mathbf{2 1}^{\text {st }}$ century sustainable development: lessons and opportunities for the BRICS-led New Development Bank. New Delhi: O.P. Jindal Global University, 2017.

\section{COMPLEMENTARY BIBLIOGRAPHY}

ADB - ASIAN DEVELOPMENT BANK. Investing in sustainable infrastructure: improving lives in Asia and the Pacific. Philippines: ADB, 2009.

ANG, H. G.; MONZONI, M. Large-scale projects in the Amazon: lessons learned and guidelines. São Paulo: FGV EAESP, 2017.

BHATTACHARYA, A.; OPPENHEIM, J.; STERN, N. Driving sustainable development through better infrastructure: key elements of a transformational program. Washington: Brookings Institution, 2015. (Working Paper, n. 91). Available at: <https://www.brookings.edu/wp-content/uploads/2016/07/07sustainable-development-infrastructure-v2.pdf>.

EURASIA CENTER; EURASIAN BUSINESS COALITION. The 3rd annual "Doing business with the BRICS" conference. Washington: [s.n.], 2015. Available at: <https://cdn.website-editor.net/9cbc1728769a439897acc7f1557971d9/files/ uploaded/3rd\%2520Annual\%2520BRICS\%2520Conference\%25208-5-2015.pdfs.

SURYANARAYANA, M. H. Inclusive growth: a sustainable perspective. Mumbai: Indira Gandhi Institute of Development Research, 2013.

VAZQUEZ, K. C.; LUCEY, A. Advancing South-South cooperation in education and skills development: lessons from the field. New York: UNDP, 2016.

VAZQUEZ, K. C.; ROYCHOUDHURY, S.; BORGES, C. New Development Bank is BRICS' best card. Financial Times, 5 Sep. 2017. 
